\title{
GROWTH AND GOVERNMENT:
}

\section{IS THERE A DIFFERENCE BETWEEN DEVELOPED AND DEVELOPING COUNTRIES?}

\author{
Tove Strauss ${ }^{* *}$ \\ Working Paper Series in Economics and Finance No. 275
}

October 1998

\begin{abstract}
We examine the role of government for growth in 64 industrialized and developing countries, considering both expenditure and financing aspects of government. Recognizing that there are differences between the two country groups leading to severe heteroskedasticity, we use weighted least squared estimations. The general conclusion is that the means of financing matters more for growth than do government spending. We find that seigniorage and budget surplus are important for growth in LDCs but not in industrialized countries, while capital revenue matters only in the latter group. Moreover, the level of indebtedness is a negative determinant of growth in LDCs.
\end{abstract}

JEL: C210; E620; H540; H630; O400

Key words: Growth; Government; Public expenditure; Public financing.

\footnotetext{
* This paper has benefited from comments by Göte Hansson, Sara Johansson, Sune Karlsson, Ari Kokko, Xavier Salai-Martin, Anna Sjögren, Mario Zejan, Fabrizio Zilibotti, Lars-Erik Öller and seminar participants at the Stockholm School of Economics. The comments from an anonymous referee were also helpful. In addition, I am grateful to Aysel Basci, William Easterly, Giuseppe Iarossi, Jong-Goo Park and Joakim Skalin for invaluable assistance with the data material. All errors and inconsistencies are mine.

** Department of Economics, Stockholm School of Economics, Box 6501, 11383 Stockholm, SWEDEN, Email: gted@hhs.se, Telephone: + 46873692 58, Fax: + 468347818
} 


\section{Introduction}

Government is controversial. The role of government for economic growth has been widely discussed in economic literature, particularly since the early 1990s. The "East Asian miracles" were referred to as examples of what has been called "good governance" (although the recent Asian crisis has challenged this), while several governments in Sub-Saharan Africa have appeared to be counterproductive in their efforts to foster long-term development. The purpose of this paper is to systematically examine if the role of government activity for growth in developing countries, countries that often suffer from low levels of public infrastructure and have little or no access to domestic capital, differ from that in the industrialized countries. In what follows, the relations between growth and total government expenditure, government consumption expenditure and public investment will be examined. The recent resurgence in the debate about debt relief for the most severely indebted countries (the Heavily Indebted Poor Country Debt Initiative) has also motivated a discussion of the role of government financing for growth. ${ }^{1}$

Actions taken by the government are often assumed to have considerable effects on macroeconomic performance. For instance, the composition and credibility of government policies may influence private capital formation and the rate of growth in the economy. The level of public expenditure may have external effects on private investment and may also affect the long run growth rate. There exists a rich empirical literature on the effects of public expenditure on growth. The existing studies do, however, give quite contradictory results for different types of public expenditures. Some studies, e.g. Ashauer (1989), Baffes and Shah (1993) and Shah (1992) find a growth enhancing role of public expenditure, while other, such as Kormendi and Meguire (1985) and Levine and Renelt (1992), find the opposite, namely that public expenditure reduces the rate of growth. It may also be the case that even though government spending has a positive impact on growth by enhancing the marginal productivity of private capital, this effect may be offset by the negative effect of distortionary taxation. ${ }^{2}$

This paper adds a novelty to earlier research by explicitly comparing developing and industrialized countries, correcting for heteroskedasticity between the two groups using the method of

\footnotetext{
1 See the Economist (1996) and the IMF (1996).
} 
weighted least square analysis (WLS), and by including both disaggregated expenditure and financing measures of government activity in the regression analysis. The role of government for growth is of particular interest in countries undergoing structural adjustment where government expenditure is often drastically reduced while the role of the private sector is still not well defined.

The paper is organized as follows. The second section provides a theoretical discussion of the role of government for growth, using the framework of the Barro (1990) model. In the third section, results from previous empirical studies are briefly presented. The analysis of the effects of government expenditure on growth is undertaken in the fourth section, while the analysis of the effects of government financing on growth is undertaken in section five. The role of aid and indebtedness for growth in developing countries is investigated in section six and interpretation of the results and the conclusions are given in the seventh and final section of the paper.

\section{Theoretical framework}

The empirical analysis in this paper is conducted within the framework of standard neoclassical and new growth models, using Barro-type growth regressions. ${ }^{3}$ Two kinds of variables are entered into the regressions: initial values of a set of state variables and a set of environmental or control variables. The following growth function is constructed:

$$
\dot{y}_{t}=F\left(\mathbf{s}_{\mathbf{t}-1}, \mathbf{e}_{\mathbf{t}}\right)
$$

where $\dot{y}_{t}$ is the per capita GDP growth rate, $\mathbf{s}_{\mathbf{t}-\mathbf{1}}$ is a vector of state variables and $\mathbf{e}_{\mathbf{t}}$ is a vector of environmental and control variables. $\mathbf{s}_{\mathbf{t}-\mathbf{1}}$ consists of variables such as the stock of physical and human capital, while $\mathbf{e}_{\mathbf{t}}$ consists of variables such as government activity, population growth and private investment. While the environmental and control variables determine the steady-state level of per capita output in the economy, the state variables determine the speed of convergence towards the steady state.

\footnotetext{
2 See e.g. Barro (1990).

3 The so-called Barro-type regressions were first presented in Barro (1991).
} 
In order to investigate the relations between public and private capital, the analysis in this paper relies on the work by Barro (1990). Barro presents a simple model of endogenous growth, where the interaction between private and public capital is elegantly captured. The model predicts the influences on growth from imbalances between private and public capital. Public capital is in this model interpreted as a measure of public services provided in the economy. ${ }^{4}$ Public services are considered inputs to private production and it is this complementarity between public and private capital that creates a potentially positive linkage between government services and growth in the model. Government services can be thought of as a flow in the sense that the government buys a flow of output from the private sector and makes it available to all households. These services correspond to the input that matters for private production. ${ }^{5}$ The point of including public capital as a separate argument of the production function is that private inputs are not always close substitutes for public inputs and in many developing countries user charges have proven difficult for private producers to implement. ${ }^{6}$ The government therefore has a role to play as a provider of certain goods, as argued by Devarajan et al. (1996).

One drawback of the Barro (1990) model is the assumption that government spending is financed through income taxes, requiring a budget balance in each period. A model better suited for the empirical analysis of particularly developing countries would give room for alternative ways of public financing and relax the assumption of Ricardian equivalence. ${ }^{7} 8$ The government's ability to tax the domestic population is often limited in poor countries where consumption is already at or near subsistence levels and may not be further reduced. Thus, when households are facing increased taxes,

\footnotetext{
${ }^{4}$ In the formal model, it is not clear whether public capital should be measured in stock or flow data (i.e. investment, or even incorporating consumption). In the empirical analysis that follows, data availability only permits analysis of the effects of flow data.

5 As long as the government and the private sector have the same production function, the result would be the same if the government buys private inputs and engages in production itself, instead of purchasing only final output from the private sector.

${ }^{6}$ Consider e.g. public services such as national defense and the maintenance of law and order.

${ }^{7}$ The Ricardian Equivalence Theorem states that, for any given path of government consumption, households do not change their consumption path in response to a change in the timing of taxes. More specifically, a decrease (increase) in government savings, corresponding to an increase in government debt, is perceived as an indication of higher (lower) future taxes to finance future repayments of the debt, and hence of higher (lower) need for individual savings in the present. If Ricardian equivalence holds perfectly, changes in government savings will therefore be fully offset by changes in private savings, leaving aggregate national savings unchanged.

${ }^{8}$ Greiner, Semmler and Gong (1997) make such an attempt.
} 
they will have to reduce savings, which in turn will lower growth of private capital. Furthermore, tax administration may be inadequate. It follows that international public borrowing as a means of financing investments has often been the only viable alternative. Several authors have found a significant negative effect of the external debt to GDP ratio on private investment, providing support for debt overhang effects. ${ }^{9}$ As the purpose of this paper is not to build and estimate a full-scale structural model of economic growth in developing countries, various Barro-type regression models are used to illustrate the empirical effect of government activity on growth, while permitting the means of public financing to take other forms than income taxation.

One alternative form of financing is public borrowing, which can be of two kinds: the government can borrow domestically, or it can borrow on the international market (Barro, 1974, 1989). ${ }^{10}$ Following the traditional arguments of crowding out, in a country with imperfect capital markets domestic public borrowing may increase domestic interest rates and reduce growth. Moreover, increasing costs of borrowing implies an increasing future tax burden, which may inhibit private investment (debt overhang). International public borrowing is often of importance for low income countries with an imperfect capital market, a small tax base and inefficient tax collection. However, increased public indebtedness will reduce the overall solvency of a particular country, which may affect both public and private investors who borrow on the international market. Rising costs of borrowing may again lead to additional future tax increases as well as crowding out of private investment.

A third alternative mean of financing is capital revenue through the sales of non-financial capital assets. A fourth alternative is non-tax revenues such as fees and other charges and a fifth option for developing countries is, of course, the receipt of unrequited transfers such as official grants. ${ }^{11}$ The separate effects of these financing variables on growth will be investigated in the empirical analysis that follows.

\footnotetext{
${ }^{9}$ Agénor and Montiel (1996), p. 86, mention several studies of debt overhang effects.

10 Assuming that Ricardian equivalence holds, public borrowing will lead to precautionary saving and will not affect growth. However, as noted earlier, precautionary saving may be impossible if consumption is already at a subsistence level. Moreover, without perfect capital markets, Ricardian equivalence does not necessarily hold.

${ }^{11}$ Seigniorage, which in the short-run may finance government spending, is one type of non-tax revenue. This has been used by some developing countries with severely negative consequences. Particularly, the resulting uncertainty may be detrimental for long-run growth rates.
} 
The following identity describes the financing of government expenditure in the economy:

$$
G_{t}=T_{t}+B_{t}+C R_{t}+N T_{t}+A_{t}
$$

where $G_{t}$ is public capital, $T_{t}$ are taxes collected in the economy, $B_{t}$ is public borrowing and the use of reserves, $C R_{t}$ is capital revenue, $N T_{t}$ is non-tax revenue in the public sector and $A_{t}$ are official grants. $^{12}$

\section{Previous empirical findings}

The empirical literature on the effects of government on growth is vast but inconclusive. Most of the literature has covered both industrialized and developing countries, while focusing on the expenditure side of government activity. Few studies cover the effects of government financing comprehensively and the methodologies used in the different analyses also vary between authors. Here, some of the previous empirical work on the effects of government on growth is presented. However, none of the articles described below capture what this paper intends to capture, namely how the role of government differs between developing and developed economies while considering both the effects of government expenditure and government financing. ${ }^{13}$

In an early influential article, Kormendi and Meguire (1985) examine cross-sectional relations between economic growth and a number of macroeconomic variables in 47 countries. The study covers the period between 1950 and 1977 and uses data mainly from the International Finance Statistics (IFS). In the regression analysis, the explanatory variables are entered independently and linearly, testing whether specific variables motivated by standard macroeconomic hypotheses are related to economic growth. Their main findings of interest for the present study is that growth of money supply is a positive and significant determinant of real GDP growth, ${ }^{14}$ while the variability of monetary shocks is a substantial negative determinant of growth. Worth noting is also that the authors found no evidence that growth of government consumption adversely affected economic growth.

\footnotetext{
12 In the empirical analysis that follows, public capital, $G_{l}$, is the equivalent of public expenditure, which incorporates both government consumption and government investment.

13 Devarajan et al. (1996) make an attempt to capture how the role of government expenditure differs between developed and developing countries.

14 If Brazil is dropped from the sample the coefficient is insignificant, as postulated by the theory of monetary neutrality.
} 
Barro (1991) investigates the determination of economic growth in a cross-section of countries. The study includes 98 countries and covers the period 1960-1985, using data mainly from the Summers and Heston database (Penn WT 5.6). Just like in Kormendi and Meguire (1985), the explanatory variables are entered independently and linearly. Although the study's main focus is on the role of convergence and human capital, some government-related variables are also included in the analysis. Growth of real per capita GDP is found to be negatively related to government consumption and not significantly related to public investment. ${ }^{15}$

Yet another important article is written by Levine and Renelt (1992). Using a method of extreme bound analysis (EBA), the authors examine whether the conclusions of a wide range of growth studies are robust or fragile to small changes in the conditioning information set. Following Kormendi and Meguire (1985), the explanatory variables are entered independently and linearly in the cross-section growth regression analysis. Their study covers 119 countries over the period 1960-1989 using both IFS and Summers and Heston data. Among the variables included in the study are several proxies for government activity, such as government expenditure, government consumption, government budget surplus, inflationary financing and tax revenue. Although negative and significant in some estimations, neither total government expenditure nor government consumption prove to be robust determinants of per capita GDP growth. The government budget surplus is a positive and significant determinant of growth but also turns out to be sensitive to the conditioning set of information in the regression analyses.

Easterly and Rebelo (1993) investigate the effects of fiscal policy on per capita GDP growth in cross-section as well as pooled cross-section regression analyses. ${ }^{16}$ The purpose of their article is to provide a comprehensive summary of the statistical relation between fiscal policy variables, the level of development and the rate of growth. The study covers a data set of about 100 countries for the period between 1970-1988 using data from Summers and Heston, IFS and the Government Finance Statistics (GFS).

\footnotetext{
15 Whenever government-related variables are introduced, the sample is reduced to 76 countries and only covers the period 1970-1985.

${ }^{16}$ Decade averages of all variables are used in the pooled regressions.
} 
Among the fiscal policy variables included in their study are government budget surplus, aggregated as well as disaggregated measures of government revenue, and aggregated as well as disaggregated measures of government expenditure. The main findings of relevance for this study are that most fiscal variables are not significantly related to economic growth. Moreover, the results depend heavily on the control variables included in the regression analyses. In their sample, there is also a serious problem of multicollinearity, where the fiscal variables are highly correlated with initial income and among themselves. Nevertheless, public investment in transport and communication turns out to be a positive and the only robust determinant of growth.

Devarajan et al. (1996) investigate how a change in the composition of government expenditure may affect economic growth. Using panel data with five-year forward-moving averages, the analysis covers 43 developing countries from 1970 to 1990 using data from the GFS and the IFS. Their main findings are that, when controlling for total government expenditure, current public expenditure has a positive effect on economic growth, while the relation between the capital component of public expenditure and growth is negative in their sample of only developing countries. ${ }^{17}$ This result stands in sharp contrast to the findings of previous studies that cover both industrialized and developing countries. However, for a sample of 21 industrialized countries, both variables change sign.

From the above, it can be concluded that the empirical evidence concerning the impact on growth of most forms of public spending has so far been ambiguous. Evidence by Baffes and Shah (1993), Devarajan et al. (1996) and Diamond (1989) also shows that the impact of government spending may be contingent on what the government spends its resources on. Due to the standard classification of public spending into current and capital expenditure, researchers often face problems of how to distinguish between government investment (which is generally considered to be growth enhancing) and government consumption (which is generally not considered growth enhancing). For example, Devarajan et al. (1996) point out that maintenance and operations expenditures often make capital goods more productive, although they are classified as current expenditure. Likewise, some capital

${ }^{17}$ In Devarajan et al. (1996) current and capital expenditure are expressed in shares of total government expenditure rather than in shares of GDP. Total government expenditure is expressed as a share of GDP and the coefficient is insignificant for the sample of developing countries. 
investment may due to severe corruption end up as consumption goods for the powerful elite in some developing countries, although still classified as capital expenditure.

\section{The analysis}

The focus of the analysis in this paper is on less developed countries (LDCs). There is reason to believe that the role of government in such countries may differ from that in the developed countries (DCs), where allocation mechanisms for private capital are more efficient. Hence, in the regression analysis that follows, we will investigate whether the role of government for growth is significantly different in the industrialized and the developing countries. A list of the countries included is presented in Appendix 1. Unlike earlier studies, we also correct for severe heteroskedasticity between the two groups using WLS and we consider both expenditure as well as financing aspects of the government.

In the regression analysis that follows, the impact on growth of several variables measuring government activity and the financing of such activities will be investigated. Government activity is measured along several disaggregated dimensions, such as total government expenditure, government consumption expenditure, public investment and the interaction between public and private investment. External public borrowing, capital revenue, official grants, taxation, non-tax revenue and a change in the monetary base measure government financing. ${ }^{18}$ A more detailed description of the data is presented in Appendix 2.

In order to investigate whether developing countries in fact differ from developed countries, a few variables of interest for economic growth have been compared for the two groups. See Table 1. The two independent samples are tested for differences between the population means, using the Students t-test. The bold numbers distinguish cases where the means are different between the two groups at the ten per cent level of significance. Looking at Table 1, it appears that all the selected variables except the budget surplus differ between the two groups of countries.

Now, does the government play a different role for growth in countries that are poor and capital constrained? Through a systematic disaggregation of government expenditure and financing variables 
this paper will, given the available data, analyze the role of government for growth in 21 developed and 43 developing countries between 1970 and 1992, following the structure of Levine and Renelt (1992). ${ }^{19}$

First, we examine whether total government activity has a significant impact on economic growth, using as a proxy average total government expenditure, while controlling for government deficit financing. ${ }^{20}$ Thereafter, total government expenditure is divided into its two components government consumption and public investment, in order to investigate whether it matters what the government spends its resources on. The role of public investment will be investigated both as a separate regressor as well as an interaction term, to examine the possible complementary effect of private and public investment along the lines of Barro (1990). Previous studies have examined several of these issues for a broad set of countries. One purpose of this paper is to determine whether the findings about the role of government hold true for a smaller set of countries with specific characteristics, namely developing economies.

In the fifth section of this paper, we test whether the different measures of government financing affect the rate of growth in the economy, using as proxies disaggregated measures of total government revenue, while again controlling for government deficit financing. Total government revenue is separated into its two components, current and capital revenue in order to investigate whether it matters how the government finances its expenditure. Current revenue will then be separated into its two components, tax and non-tax revenue. In addition, the role of seigniorage will also be investigated.

\subsection{The method of analysis}

In the regression analysis, like in many other cross-country growth regressions, the explanatory variables are primarily entered independently and linearly: ${ }^{21}$

18 Optimally, disaggregated data on domestic public borrowing, expenditure on defense and education, public enterprise investment and general government investment would have been incorporated in the analysis. Due to lack of data for these variables, however, they have not been included.

${ }^{19}$ It should be noted that there might be a problem of selection bias in the sample of LDCs, due to the lack of data for many of the developing countries. This selection bias would tilt the results toward positive effects of government if it were the case that only well-managed economies could provide data.

20 Government deficit financing is measured by the government budget surplus, which is equivalent to the negative sum of borrowing and the use of reserves.

21 This method is based on the work of Kormendi and Meguire (1985) as well as of Levine and Renelt (1992). 


$$
\dot{Y}=\beta_{i} \mathbf{I}+\beta_{m} \mathbf{M}+\beta_{z} \mathbf{Z}+u
$$

where $\dot{Y}$ is the per capita rate of GDP growth, $\mathbf{I}$ is a set of base regressors (the conditioning set of information), $\mathbf{M}$ are the government-related variables of particular interest, and $\mathbf{Z}$ is a subset of control variables measuring government deficit financing.

In the analysis, the dependent variable, $\dot{Y}$, is measured as the average annual growth rate of per capita GDP (GYP). Proxies for four variables identified in earlier studies as important determinants for economic growth were used as the conditioning set of information (the $\mathbf{I}$-variables). The four variables are: average total investment share of GDP (INV), the natural logarithm of per capita real GDP in 1970 (LNY70), the average annual rate of population growth (POP), and the average years of secondary schooling in the population above 25 years of age (SYR). Using the log form of the initial per capita GDP, the coefficient of this variable represents the rate of convergence to the steady state.22 Standard economic theory predicts the sign of the coefficients for the investment and human capital variables to be positive, while the coefficients for initial income and population growth should be negative (Barro and Sala-i-Martin, 1995).

\subsection{The role of government}

Having thus characterized the basic set-up, focus turns to the role of government. A number of separate $\mathbf{M}$-variables are included to examine the effects of government on growth in the regression analysis. ${ }^{23}$ The $\mathbf{M}$-variables measuring government activity are: total government expenditure (TEXP), government consumption expenditure (CUREXP), public investment (CAPEXP) and the combined effect of private and public investment (PRIVPUB). Capital revenue (CAPREV), current revenue (CURREV), tax revenue (TAX), non-tax revenue (NTAX) and seigniorage (SEIG) measure means of

\footnotetext{
22 The coefficient for initial per capita income is often used to test the convergence hypothesis (i.e. that poor countries tend to grow faster than richer countries, ceteris paribus).

${ }^{23}$ Cross-section growth regressions like these are often subject to criticism for endogeneity (simultaneity) of the explanatory policy variables. Measures of govemment activity are particularly sensitive to this type of criticism as it can easily be argued that government expenditure as well as financing are policy variables that are altered in direct response to the rate of growth in the economy. The issue of simultaneity will be further discussed below.
} 
financing these activities. ${ }^{24}$ All variables except seigniorage are expressed as period average shares of GDP. Seigniorage is measured as the average yearly growth rate of the monetary base. A list of all variables included in the analysis is presented in Appendix 3. A correlation matrix for the variables included in the subsequent regression analysis is presented in Table 2 below.

As mentioned earlier, the problem of simultaneity for this set of $\mathbf{M}$-variables is potentially large. ${ }^{25}$ Although there are ways of addressing this problem, none are particularly successful. One alternative is to estimate the regressions with the two stage least square method (2SLS), using instruments for the explanatory government-related variables. Such instruments could e.g. be initial or lagged values of these variables. However, this method severely reduces the total number of observations in the sample, as there is severe lack of data in the early 1970s. In addition, data for a single year may be less reliable than a period average. Moreover, when using lagged values as instruments, the estimation period must be split in half. As a result, the length of the cross-section growth period is severely shortened and the importance of the government-related variables is substantially reduced as the amount of short-term noise in the regression analysis increases. ${ }^{26}$ Most importantly though, the use of initial or lagged values as instruments fails to capture the contribution of these variables over the estimation period, which is the main purpose of this study. Consequently, this study, like many other cross-section studies in the literature, uses data for government-related variables averaged over the relevant study period, however, bearing in mind the potential problems involved. ${ }^{27}$

Since the original sample includes both industrialized and developing countries, all preliminary regression have been checked for heteroskedasticity, using the Goldfeld-Quant test. ${ }^{28}$ As heteroskedasticity between the two groups prove to be a serious problem, the regression equations are

\footnotetext{
24 The influence of official grants (AID), the level of indebtedness (DEBT) and the debt service ratio (DSR) on economic growth will be investigated separately for the developing countries.

25 For an extensive discussion of the problems of simultaneity, see Kelly (1997).

26 The optimal length of a period measuring economic growth is disputed among macroeconomists. Barro and Sala-iMarin (1995) argue that 15 years is a suitable minimum. When instruments are used in weighted 2SLS regressions for the period 1981-92, the adjusted R-squared falls and the level of significance for all government-related variables is altered either upwards or downwards, when compared to WLS estimates for the same period. Comparing the estimates of the weighted 2SLS regressions with the period 1970-92 WLS estimates, the adjusted R-sqared is always much higher in the WLS regression and the same holds true for most of the government-related variables.

27 See e.g. Barro (1991), Easterly and Rebelo (1993), Kelly (1997), Levine and Renelt (1992) and Nelson and Singh (1994). The only exception referred to in this paper is Devarajan et al. (1996).
} 
estimated using WLS. ${ }^{29}$ Furthermore, using the same weights, dummy variable regressions (DVR) with dummies for both groups are estimated in order to investigate if the role of government differs between DCs and LDCs. Although the Goldfeld-Quant method is without doubt here superior to White's method of correcting for heteroskedasticity, it has not been used previously in the literature. Thus, there may be reason to question the acccuracy of earlier results for studies covering both sets of countries..$^{30}$

\section{Total government expenditure (TEXP)}

In order to investigate the role of general government activity for growth, a variable measuring total government expenditure is introduced as the first $\mathbf{M}$-variable along with the four $\mathbf{I}$-variables and one $\mathbf{Z}$-variables measuring government budget surplus (GSUR). ${ }^{31}$ The regression results are presented in Table 3. All the $\mathbf{I}$ - and $\mathbf{Z}$-variables are significant at the ten per cent level with the predicted signs in regression equation 1.32

The $\mathbf{M}$-variable is equivalent to the sum of government consumption and government investment. As argued by Levine and Renelt (1992), an aggregate measure of government activity will not capture potentially important implications of how expenditures are allocated. Government expenditure involves public services as well as bureaucracy. Hence, total government expenditure may not only be a measure of public goods, but also of public "bads", i.e. unproductive public expenditure. Subsequently, there is no prior regarding the sign of the coefficient for total government expenditure.

\footnotetext{
28 The Goldfeld-Quant test is a more powerful test than White's test for groupwise heteroskedasticity that is normally used in least square regression analysis. See Greene (1993).

29 Groupwise estimated variances are used as weights. In addition, all weighted regressions are also corrected for heteroskedasticity using White's method whenever called for

${ }^{30}$ Comparing the results of OLS and WLS regression analysis, the WLS increases the adjusted R-squared markedly. Moreover, the WLS method clearly affects the level of significance for all government-related variables, some upwards and some downwards.

31 As total government expenditure incorporates public investment, private investment is entered in regression equations 1-3 as an I-variable, in order to avoid multicollinearity. Optimally, control variables for all types of government financing should be included, but due to problems of multicollinearity, this is not feasible.

32 Contrary to the findings of Levine and Renelt (1992), population growth is significantly negative in the regression analysis. This results may stem from the fact that population growth is a serious problem in many developing countries, where population growth rates are generally considerably higher than in the industrialized world. It should also be noted that the causality between growth and investment is still under debate. See e.g. Barro and Sala-i-Martin (1995), Blomström, Lipsey and Zejan (1996) and Levine and Renelt (1992).
} 
Moreover, since total government expenditure is highly correlated with total government revenue, it is almost impossible to distinguish the effects of the two separate variables in the regression analysis. ${ }^{33}$

Contradicting the findings of Levine and Renelt (1992), TEXP does not turn out to be a significant determinant of growth. There may be two possible reasons for this result. One is that the level of government expenditure simply does not matter for growth. Another is that the two separate components of total government expenditure, namely capital and current expenditure, may have contradicting effects on the rate of growth in the economy. Looking at the dummy variable regression, TEXP remains to be an insignificant explanatory variable of economic growth in both LDCs and DCs.

\subsection{Government spending - what matters?}

An aggregate measure of government size such as total government expenditure does not capture the potentially important implication of how government expenditure is allocated between current and capital expenditure. Evidence from previous empirical studies suggest that the impact of government spending has often been contingent on what the government spends its resources on (Baffes and Shah, 1993, Devarajan et al., 1996 and Diamond 1989). Hence, in regression equation 2, total government expenditure is disaggregated into its two components, current expenditure and capital expenditure.

\section{Government consumption (CUREXP)}

Government consumption is not expected to have any direct effect on private productivity, while it may lower both savings and growth through the indirect effect of increased distortionary taxation (Barro, 1991). Just like in Kormendi and Meguire (1985), the relation between growth and government consumption in regression equation 2 is insignificant. The reason behind this is presumably the effect of nonproductive government consumption expenditure, such as oversized and inefficient government administrations as well as distortionary subsidies, which are particularly prominent in many developing countries. In contrast to the work of Barro (1991) and Barro and Sala-iMartin (1995), expenditure for defense and non-capital outlays for education, which they expect to be

33 The correlation coefficient between the two variables is 0.93 . The effects of e.g. taxes necessary to support government spending may distort incentives and reduce efficient resource allocation (Kormendi and Meguire, 1985). 
positive determinants of growth, have not been subtracted in this study due to the subsequent loss of data. In the dummy variable regression, government consumption remains to be an insignificant determinant of growth in both subgroups.

\section{Government investment (CAPEXP)}

Following the predictions of the Barro (1990) model, public investment is expected to be a positive determinant of growth. Public investment is, however, not a significant determinant of growth in regression equation 2, confirming the findings of the empirical analysis in e.g. Barro (1991) and Levine and Renelt (1993). In the dummy variable regression, public investment remains an insignificant determinant of growth in both subgroups. This result contradicts the findings of Devarajan et al. (1996), who find the coefficient to be significant and negative in LDCs but significant and positive in DCs.

\section{Interaction effects (PRIV PUB)}

Reasoning along the lines of Barro (1990), we will now investigate if the complementary relationship between public and private capital has any consequences for growth. The Barro (1990) model predicts that government services will crowd in private investment and raise growth. This relation should be of particular importance in the LDCs, where the government generally plays a larger role in the process of capital formation than in the industrialized countries (Agénor and Montiel, 1996).

However, one must keep in mind that different types of public investment are quite likely to have different implications for the accumulation of private capital as well as for growth. As public investment in many developing countries does not only include basic infrastructure projects but also commercial and industrial projects of large parastatals, public investment may compete with private firms and crowd out private investment, using scarce resources that would otherwise be available to the private sector. ${ }^{34}$ This may lead to higher interest rates, credit rationing and a higher future tax burden (Oshikoya, 1994 and Servén, 1996).

\footnotetext{
${ }^{34}$ Looking at the size of the coefficients in regression equation 2, it is clear that private investment has a larger impact on growth than does public investment.
} 
In order to study the possible interaction effect between public and private investment, a new regressor is constructed by multiplying the private and public investment variables. This new variable (PRIVPUB) is included separately in regression equation 3. However, in the presence of severe multicollinearity between private investment and the new interaction term, the coefficient for the interaction effect as well as for the two investment variables are insignificant in the regression analysis. Thus, looking at all countries, little can be said about the possibility of an underlying complementarity between public and private investment. In the dummy variable regression, however, the new variable becomes a significant positive determinant of growth in the developed countries, indicating that there are in fact complementary effects between public and private investment in this subset of countries. The coefficient for public investment by itself also becomes significant, but with a negative sign. These results indicate that private investment is needed in order for the negative effect of public investment not to dominate.

In sum, we find that all but one of the aggregate or disaggregated measures of government expenditure have no significant effects on growth rates in either industrialized or developing countries. The only significant effect to be found is the negative effect of capital expenditure in DCs, when controlling for the complementary effect of private investment.

\section{Public financing}

In the above analysis of the effects of government expenditure on growth, one important factor has not been discussed explicitly, namely, the means of financing. How a government chooses to finance its activities may have significant consequences for growth. If the means of financing are costly, a positive effect of public expenditure may be outweighed by the negative effect of its financing. In this section, the effect on the rate of growth of different measures of government revenue will be analyzed, while again controlling for government deficit financing.

The purpose of this study is not to investigate what factors determine government expenditure. Rather, government expenditure and their means of financing are taken as given. The objective is to determine whether the means of financing government expenditure have systematic implications for growth. The role of the debt service to export ratio (DSR), as well as the level of indebtedness as a 
share of GDP (DEBT) will also be investigated for the LDCs. Optimally, a variable measuring domestic public debt should be included in the analysis, but due to lack of data this variable has not been possible to construct.

As in the previous section, four I-variables: INV, LNY70, POP and SYR, are included in all regressions. In addition, total government is disaggregated into two components: current revenue (CURREV) and capital revenue (CAPREV). ${ }^{35}$ In a second stage, current revenue is disaggregated into its two components: taxation (TAX) and non-tax revenue (NTAX). Later, the amount of seigniorage (SEIG) measured by the growth rate of the monetary base is entered as a separate regressor. ${ }^{36}$ These variables are introduced as the new $\mathbf{M}$-variables in the regression analysis. The variable measuring government deficit financing (GSUR) is again included as a control variable (Z-variable). A correlation matrix for the revenue variables is presented in Table 4 and the regression results are presented in Table 5 .

\section{Capital revenue (CAPREV)}

Capital revenue includes payments or receipts for the acquisition, construction or sale of nonfinancial assets (IMF, 1986). The coefficient is expected to be positive as the sale of government assets in many countries particularly involves the sale of inefficient state enterprises that are counterproductive to economic growth. Disaggregating total government revenue into its two separate components, current and capital revenue, capital revenue turns out to be a positive and significant determinant of economic growth in regression equation 4. This result confirms the finding of Easterly and Rebelo (1993). Somewhat surprisingly, in the dummy variable regression, capital revenue is only a significant and positive determinant of growth in the group of industrialized countries.

\section{Current revenue (CURREV)}

Current revenue consists of both tax and non-tax revenue. As the effect of taxes on growth are expected to be negative, while the effect of non-taxes is inconclusive (see below), the sign of the

\footnotetext{
35 Total government revenue is not introduced as a separate regressor due to its high correlation with total government expenditure. See section 4.2.

36 Seigniorage actually constitutes a part of non-tax revenues but cannot be easily disaggregated. However, due to the low correlation between the two variables, they are entered simultaneously in the regression analysis.
} 
coefficient of current revenue is also inconclusive. Perhaps then not so surprisingly, the coefficient for CURREV is insignificant in regression equation 4. The coefficient remains insignificant for both country groups in the dummy variable regression. Moreover, since current revenue is highly correlated with total government revenue, it is almost impossible to distinguish the effects of the two separate variables in the regression analysis. ${ }^{37}$

\section{Tax revenue (TAX)}

Due to the distortionary effects of most types of taxation, the effect of total tax revenue on growth is expected to be negative. However, the results in regression equation 5 indicate that the coefficient for tax revenue is not a significant determinant of growth. This result confirms the findings of Easterly and Rebelo (1993), where only one out of thirteen different tax rate variables included in their analysis has a significant coefficient. ${ }^{38}$ Looking at the dummy variable regression, the tax variable remains insignificant for both developed and developing countries. One possible explanation behind these results may be that although taxes are distortionary, only relatively successful countries are able to raise significant tax revenues. Moreover, tax collection is often inefficient in developing countries. Hence, the amount of taxes collected may be too small to have significant distortionary effects on the rate of growth in the economy.

\section{Non-tax revenue (NTAX)}

Non-tax revenue includes requited receipts such as e.g. property income, fees and charges, current private donations, seigniorage profits and non-industrial and incidental sales. ${ }^{39}$ As the variable consists of many different components, theory gives no clear indication about the sign of the effect of this variable on growth. Moreover, non-tax revenue is generally small in this sample of countries. ${ }^{40}$ However, contradicting the findings of Easterly and Rebelo (1993), non-tax revenue turns out to be an

\footnotetext{
37 The correlation coefficient between total government revenue and current revenue is 1.00. Moreover, the correlation coefficient between current revenue and total government expenditure is 0.93 .

${ }^{38}$ Easterly and Rebelo find that marginal income tax is a significant negative determinant of growth. However, data on income taxation is not sufficient for this sample to include it as a separate regressor. The authors do not report a coefficient for the effect of a variable including all taxes, comparable to TAX.

${ }^{39}$ For a detailed description of non-tax revenue components, see IMF (1986) pp. 125-9.

40 On average, non-tax revenue makes up about 15 per cent of total government revenue.
} 
insignificant determinant of growth in regression equation 5. In the dummy variable regression, the non-tax variable remains insignificant for both groups.

\section{Seigniorage (SEIG)}

Seigniorage is used as a proxy for government financing through the printing presses. Relying on the theory of monetary neutrality, economic growth will not be affected by the anticipated growth of money supply. However, the variability of money supply may increases the level of uncertainty in the economy, with negative implications for economic growth. Confirming the findings of Kormendi and Meguire (1985) and Nelson and Singh (1994) but contradicting the findings of Levine and Renelt (1992), seigniorage is a significant negative determinant of growth in regression equation 6.41 In the dummy variable regression, the coefficient for seigniorage turns out to be negative and significant only for the group of developing countries. This finding is perhaps not so surprising, as the concept of government financing through the printing presses is a much more common and widespread problem in the LDCs than in the industrialized countries. However, the size of the coefficient is not significantly different between the two groups of countries.

\section{Government budget surplus (GSUR)}

Government deficit financing through borrowing or the use of reserves has been a common phenomenon in many countries, particularly in the LDCs. The amount of publicly guaranteed debt outstanding clearly affects a government's solvency and in turn its borrowing conditions. As the amount of debt grows, creditors will naturally request shorter maturities or debt indexation due to the increasing risk of default (Giavazzi and Pagano, 1990 and Alesina et al., 1990). Whether public borrowing actually affects the rate of growth or not should depend on if Ricardian equivalence holds (Barro, 1989). It can, however, easily be argued that Ricardian equivalence does not hold in most developing countries, as capital markets are often undeveloped. Under these conditions, an increase in the public debt may affect the returns to public expenditure. A common argument has been that when

\footnotetext{
41 The authors of the mentioned studies use money supply growth (Kormendi and Meguire) and the inflation rate
} (Nelson and Singh and Levine and Renelt) as the explanatory variable. 
public expenditure is financed through public borrowing on the international market, an increase in the cost of borrowing will increase future taxes and lower growth in the private capital stock. ${ }^{42}$

The relation between government budget surplus (GSUR) as a share of GDP and growth is positive and significant in regression equations 1 and 2, confirming the arguments made above as well as the findings of Easterly and Rebelo (1993). In the dummy variable regressions it is a positive and robust determinant of growth for the LDCs in all the regression equations, while it is insignificant for the group of industrialized countries in all regressions but regression equation 3. Moreover, the coefficient for the government budget surplus in the group of LDCs is significantly different from the coefficient for the DCs in regression equations 3. These results stands in contrast to the findings of Nelson and Singh (1994), who, somewhat surprisingly, do not find government budget deficit to be a significant determinant of growth in their sample of developing countries.

Besides the argument that Ricardian equivalence does not hold in LDCs, it should be noted that another possible explanation might just be reverse causation; low growth rates may force poor countries to run budget deficits and borrow on the international market. Hence, it is perhaps not a budget deficit or increasing indebtedness that reduces the rate of growth, it may be low growth that forces countries to increase their borrowing.

In sum, we find that capital revenue is a robust and positive determinant of economic growth when all countries are included in the sample. However, the effect seems to be driven by the industrialized countries as the significant effect vanishes for the LDCs when the sample is split between the two groups. Seigniorage, on the other hand, is a negative and significant determinant of growth for the entire sample, but here the effect appears to be driven by the LDCs. The effect on economic growth of running a budget surplus is in general important. However, the result is particularly strong for the LDCs where the coefficient is positive and robust, whereas it is never significant for the industrialized countries.

\footnotetext{
42 This effect is particularly important if consumption is already at subsistence level.
} 


\section{Public financing in developing countries}

In this section, the effects of aid and public debt on economic growth will be analyzed, still controlling for government deficit financing. The regression analysis will be limited to only the developing countries for two separate reasons. One is that the data from the World Bank is limited to LDCs and the other is that problems with high indebtedness and aid dependency is associated with this particular group of countries.

\section{Foreign aid (AID), Grants (GRANT) and Technical assistance (TA)}

Many developing countries receive substantial amounts of foreign aid to finance government expenditure. The impact of foreign aid on growth has recently been the focus of studies by Boone (1995) and of Burnside and Dollar (1996). ${ }^{43}$ In the present study, foreign aid is measured as the average share of official grants to GNP (AID), i.e. not including concessional lending. Official grants consist of two separate components, namely regular official grants and technical assistance grants. A correlation matrix for the new variables is presented in Table 6.

The effect on growth of unrequited transfers such as official grants is expected to be positive. Hence, ceteris paribus, countries that finance government expenditure with foreign assistance instead of with taxes that bring about distortionary effects are expected to grow faster. The relation between growth and AID is, however, significantly negative in regression equation 8 . This result is most likely a consequence of reverse causality due to the underlying fact that unrequited transfers are generally given to capital constrained economies experiencing low growth. Hence, a potential positive effect of aid on growth may not be detected using this method of cross-section regression. The regression results are presented in Table 7.

The two separate components of AID are separated into regular grants (GRANT) and technical assistance (TA) in regression equation 9. GRANT remains to be a negative and significant determinant of growth, while the coefficient for TA turns out to be insignificant.

\footnotetext{
43 Boone finds no significant correlation between foreign aid and the rate of growth in developing countries, while Burnside and Dollar find foreign aid to be a positive determinant of growth when accompanied by sound fiscal, monetary and trade policies.
} 


\section{Public indebtedness (DEBT)}

During the debt crisis in the early 1980s, many heavily indebted developing countries experienced severely reduced levels of economic growth and the overwhelming proportion of the external debt outstanding was publicly owed (Agénor and Montiel, 1996). ${ }^{44}$ In many developing countries, parastatal companies are common. When these companies borrow on the international market, the debt is frequently guaranteed by the government, so called publicly guaranteed debt, increasing the overall debt burden of the country.

A variable measuring the average level of external indebtedness to GNP (DEBT) is introduced in regression equation 10. Following the argumentation above, the relation between the level of indebtedness and growth is negative and significant as expected.

\section{Debt service ratio (DSR)}

In the light of many years of discussing the importance of debt reductions for the capital constrained developing countries, it is of obvious interest to examine whether the burden of external debt has an effect on the rate of growth in LDCs. A high debt service ratio is one factor that is often argued to be a major constraint for these countries. In regression equation 11, a variable measuring the average debt service to export ratio (DSR) is introduced, expected to affect growth negatively. However, the coefficient for this variable proves to be insignificant. As debt forgiveness has often been a measure taken to alleviate the foreign currency constraint for developing countries, this finding is quite surprising. In this sample of 38 developing countries, all but six benefited from debt forgiveness at one point or another.

Summarizing, we find that aid and the disaggregated measures of aid all are significant negative determinants of economic growth in developing countries. However, the causality of this relationship must be seriously disputed. Moreover, we find that the level of indebtedness also puts a strain on economic growth, while the debt service ratio does not affect growth significantly.

\footnotetext{
${ }^{44}$ For most developing countries, the ratio of external public debt to GDP has generally been considerably higher than the ratio of domestic public debt to GDP.
} 


\section{Interpretation of results and conclusions}

The purpose of this paper has been to analyze how the role of government for growth in developing countries differs from that in industrialized countries. Because allocation mechanisms for private capital are assumed to be less efficient in LDCs, there is reason to believe that the role of government is different. This study has tested the significance of variables identified as possible determinants of growth in previous empirical literature. It is distinguished from earlier literature inasmuch as it focuses on the differences between the two groups of countries and because it considers both the expenditure as well as the financing aspects of government.

Unlike the earlier literature, this paper uses the method of weighted least square (WLS) in order to control for the severe heteroskedasticity between the two groups. Strong effects on the estimation results emphasize the importance of correcting for groupwise heteroskedasticity. Hence, it is clear that the method of estimation (whether it is OLS, WLS, 2SLS or pooled regressions etc.) matters a lot for the estimation results. When comparing the findings of this study to earlier literature, the results also prove sensitive to the conditioning set of information, a fact that has already been pointed out by both Levine and Renelt (1992) and Easterly and Rebelo (1993).

The general conclusion of this paper is that the means of government financing matters more for economic growth than do government spending, as the role of government expenditure for growth is generally insignificant. The pattern for expenditure is the same for both industrialized and developing countries, the only exception being the significant complementary effects between public and private investment that is found in the group of developed countries. However, even though there appears to be no systematic relationship between expenditure and growth, the role of good governance may still be important. One must keep in mind that other objectives besides promoting economic growth, such as e.g. redistribution of income and infrastructure maintenance, may lead governments to maintain high levels of expenditure.

Looking at the role of government financing, capital revenue, seigniorage and the government budget surplus are significant determinants of economic growth. These results seem to be driven by differences between the two groups of countries. Capital revenue proves to be a significant positive 
determinant of growth in industrialized countries, while it does not play an important role in the LDCs. ${ }^{45}$ Seigniorage, on the other hand, is a negative determinant of growth in the developing countries, while it plays no role in the industrialized countries. Moreover, the coefficient for the average government budget surplus is positive and robust in the LDCs, but insignificant in all regressions for the industrialized group of countries.

Studying only the LDCs, we find that foreign aid is a negative determinant of growth. This result is most likely a consequence of reverse causality due to the underlying fact that unrequited transfers are generally given to capital constrained economies experiencing low growth. In view of the "Heavily Indebted Poor Country Debt Initiative", recently announced by the World Bank and the International Monetary Fund, it is somewhat surprising to find that only the level of indebtedness but not the debt service ratio seems to be significantly related to growth in the analysis. With the above results at hand, the policy implications for the developing countries are first and foremost to reduce the amount of external debt, try to balance the budget and not to turn to the printing presses when government funding is scarce.

Corruption is another government-related factor that may affect growth and government efficiency in developing countries. The level of corruption varies widely between LDCs, ranging from countries like the former Zaire where the president's personal assets could barely be distinguished from the government's, to countries like Chile where corruption supposedly is as low as in Denmark. ${ }^{46}$ In a study of the effects of corruption on growth, Mauro (1995) finds that corruption is a robust negative determinant of investment, which in turn has negative implications for the rate of growth in the economy. ${ }^{47}$ Other government-related factors that have been argued to be of importance for growth are the extent to which institutions provide effectively for the implementation of laws (the rule of law), political stability, political rights, civil liberties, revolutions and coups, assassinations, peace, repudiation

\footnotetext{
45 Average capital revenue is slightly higher in the industrialized countries, although the figures are not statistically different.

46 Countries are classified by their level of corruption in an index published by the Business International Corporation (1984).

${ }^{47}$ For the countries included in this study, Mauro's data cover only 26 out of the 43 LDCs. Hence, it is not possible to investigate whether Mauro's measures of corruption would interact with the traditional government-related variables included in the analysis of this paper without substantially reducing the sample.
} 
of contracts, quality of bureaucracy and the risk of expropriation (Barro and Sala-i-Martin, 1995, Knack and Keefer, 1995 and Mauro, 1995). However, introducing each of the above-mentioned variables in the regression analysis of this paper, only a few are significantly related to economic growth. The most important variables are political rights, risk of expropriation, rule of law, repudiation of contracts and bureaucratic quality. How these variables interact with government activity is an issue for further research. 
Appendix 1. List of countries.

$\underline{\mathrm{LDCs}}^{48}$

Argentina

Bolivia

Brazil

Cameroon

Chile

Colombia

Costa Rica

Cyprus*

Dominican Rep

El Salvador

Guatemala

Guyana

Haiti

Honduras

Hungary

India

Iran

Israel*

Korea*

Lesotho

Malaysia

Malta

Mauritius

Mexico

Myanmar*

Nicaragua

Pakistan

Panama

Paraguay

Peru

Poland

Romania

Rwanda

South Africa*

Sri Lanka

Thailand

Trinidad \& Tobago

Tunisia

Turkey

Uruguay

Venezuela

Zambia

Zimbabwe

$\underline{\mathrm{DCs}}$

Australia

Austria
Belgium

Canada

Denmark

Finland

France

Germany

Greece

Iceland

Ireland

Japan

Netherlands

Norway

Portugal

Singapore

Spain

Sweden

Switzerland

United Kingdom

United States

48 Countries marked with an asterisk are not included in the separate analysis of the effects of aid and debt on economic growth. 


\section{Appendix 2}

Data for the empirical analysis have been collected mainly from the International Finance Statistics (IFS) and the Government Finance Statistics (GFS). The GFS includes data on central government expenditure and revenue. Only for a small set of countries does the GFS provide data of the local government equivalents. However, incorporating both central and local government data for the smaller set of countries, Devarajan et al. (1996) as well as Kelly (1997) have tested for differences in estimation results but found the results to be similar between the two data sets.

The data analysis covers developed and developing countries that are available from the two databases between 1970 and 1992. The former Soviet Union, the new republics of the former Soviet Union and the former Yugoslavia are excluded from the analysis. Colonies as well as newly independent countries are also excluded.

Three other major databases were used in the analysis. The Global Development Finance (GDF) includes information on debt, grants and technical assistance. The Penn World Tables (PWT5.6) include data on economic growth and population growth and the Barro and Lee database includes information on secondary education. Economic growth has been calculated as growth in real per capita GDP, where per capita income is real per capita GDP in constant 1985 international prices (Chain Index). 


\section{Appendix 3}

List of variables incorporated in the analysis.

AID Average level of official grants as a share of GNP (including technical assistance). WDI

CAPEXP Average government investment as a share of GDP. GFS

CAPREV Average capital revenue as a share of GDP. GFS

CUREXP Average government consumption expenditure as a share of GDP. GFS

CURREV Average current revenue as a share of GDP. GFS

DSR Average debt service as a share of exports. GDF

GRANT Average level of official grants as a share of GNP (excluding technical assistance). WDI

GSUR Average government budget surplus as a share of GDP. IFS

GYP Average annual growth rate of per capita real GDP. Penn WT 5.6

INDEBT Average level of indebtedness as a share of GNP. GDF

INV Average total investment share of GDP. IFS

LNY70 Initial level of the natural logarithm of per capita real GDP (1970). Penn WT 5.6

NTAX Average non-tax revenue as a share of GDP. GFS

POP Average annual rate of population growth. Penn WT 5.6

PRIV Average private investment as a share of GDP. IFS

PRIVPUB Multiplicative interaction term of PRIV and PUBI. IFS and GFS

SEIG Average annual rate of change in the monetary base as a share of the monetary base. IFS

SYR Average years of secondary schooling in the total population above 25 years of age. Barro and Lee

TA Average technical assistance as a share of GNP. WDI

TAX Average tax revenue as a share of GDP. GFS

TEXP Average total government expenditure as a share of GDP. GFS

TREV Average total government revenue as a share of GDP. GFS 


\section{REFERENCES}

Agénor, Pierre-Richard and Peter Montiel (1996) Development Macroeconomics, Princeton University Press. Alesina, Alberto, Alessandro Prati and Guido Tabellini (1990) "Public Confidence and Debt Management" in Dornbush, R. and M. Draghi (eds.) Public Debt Management: Theory and History, Cambridge University Press.

Ashauer, David A. (1989) "Public Investment and Productivity Growth in the Group of Seven" Economic Perspectives 13, No. 5, Federal Reserve Bank of Chicago, 17-25.

Baffes, John and Anwar Shah (1998) "Productivity of Public Spending, Sectoral Allocation Choices, and Economic Growth" Economic Development and Cultural Change, Vol. 46, No. 2, 291-303.

Barro, Robert J. (1991) "Economic Growth in a Cross Section of Countries" The Quarterly Journal of Economics, 407-443.

Barro, Robert J. (1990) "Government Spending in a Simple Model of Endogenous Growth" Journal of Political Economy 98, No. 5, 103-125.

Barro, Robert J. (1989) "The Neoclassical Approach to Fiscal Policy" in Barro, R. (ed.) Modern Business Cycle Theory, Harvard University Press, 178-235.

Barro, Robert J. (1974) "Are Government Bonds Net Wealth?" Journal of Political Economy 81, 10951117.

Barro, Robert J. and Xavier Sala-i-Martin (1995) Economic Growth, McGraw-Hill, Inc.

Blomström, Magnus, Robert E. Lipsey and Mario Zejan (1996) "Is Fixed Investment the Key to Economic Growth?" Quarterly Journal of Economics, Vol. CXI, Issue 1, 269-276.

Boone, Peter (1995) "The Impact of Foreign Aid on Savings and Growth" mimeo, London School of Economics.

Burnside, Craig and David Dollar (1996) "Aid, Policies and Growth" mimeo, the World Bank.

Business International Corporation (1984) "Introduction to the Country Assessment Service, Business International Corporation, New York.

Devarajan, Shantayanan, Vinaya Swaroop and Heng-fu Zou (1996) "The Composition of Public Spending and Economic Growth" Journal of Monetary Economics 37, 313-344.

Diamond, J. (1989) "Government Expenditure and Economic Growth: An Empirical Investigation" WP/89/45, IMF Working Paper.

Easterly, William and Sergio Rebelo (1993) "Fiscal Policy and Economic Growth: An Empirical Investigation" Journal of Monetary Economics 32, 417-458.

Economist, The (1996) "A Fund in Need of Funds" Vol. 341, No. 7991, 109.

Fisher, Stanley (1993) "The Role of Macroeconomic Factors in Growth" Journal of Monetary Economics 32, 485-512.

Giavazzi, Francesco and Marco Pagano (1990) in Dornbush, R. and M. Draghi (eds.) Public Debt Management: Theory and History, Cambridge University Press.

Greene, William H. (1993) Econometric Analysis, Prentice Hall.

Greiner, Alfred, Willi Semmler and Gang Gong (1997) "Estimating and Endogenous Growth Model with Public Capital and Government Borrowing", Diskussionspapier 340, Fakultät für Wirtschaftswissenschaften, Germany.

International Monetary Fund (1996) Government Finance Statistics.

International Monetary Fund (1986) A Manual on Government Finance Statistics.

Kelly, Trish (1997) "Public Expenditures and Growth" The Journal of Development Studies, Vol. 34, No. 1, 60-84.

Knack, Stephen and Philip Keefer (1995) "Institutions and Economic Performance: Cross-Country Testing Using Alternative Institutional Measures" Economics and Politics, Vol. 7, No. 3, 207-227.

Kormendi, Roger and Philip Meguire (1985) "Macroeconomic Determinants of Growth: CrossCountry Evidence" Journal of Monetary Economics, 16, 141-163.

Levine, Ross and David Renelt (1992) "A Sensitivity Analysis of Cross-Country Growth Regressions" The American Economic Review, Vol. 82, No. 4, 942-963.

Mauro, Paolo (1995) "Corruption and Growth" Quarterly Journal of Economics, Vol. CX, No. 442, 681712. 
Nelson, Michael A. and Ram D. Singh (1994) "The Deficit-Growth Connection: Some Recent Evidence from Developing Countries" Economic Development and Cultural Change, Vol. 43, No. 1, 167-191.

Oshikoya, Temitope W. (1994) "Macroeconomic Determinants of Domestic Private Investment in Africa: An Empirical Analysis" Economic Development and Cultural Change, Vol. 42, 573-596.

Servén, Luis (1996) "Does Public Capital Crowd-Out Private Capital? Evidence from India" Policy Research Working Paper 1613, The World Bank.

Shah, Anwar (1992) "Dynamics of Public Infrastructure, Industrial Productivity and Profitability" Review of Economics and Statistics 74, 28-36. 
Table 1. Cross-country variable averages, 1970-92.

\begin{tabular}{lccc}
\hline Variable & LDCs & DCs & t-value prob. \\
\hline Private investment/GDP & 0.17 & 0.21 & $\mathbf{0 . 0 0}$ \\
Years of secondary schooling 1970 & 0.58 & 1.59 & $\mathbf{0 . 0 0}$ \\
Population growth & 2.10 & 0.66 & $\mathbf{0 . 0 0}$ \\
Budget deficit/GDP & -0.05 & -0.03 & 0.12 \\
Government consumption/GDP & 0.21 & 0.30 & $\mathbf{0 . 0 0}$ \\
Public investment/GDP & 0.05 & 0.03 & $\mathbf{0 . 0 0}$ \\
Tax revenue/GDP & 0.18 & 0.27 & $\mathbf{0 . 0 0}$ \\
\hline
\end{tabular}

Table 2. Correlation coefficients for expenditure variables.

\begin{tabular}{c|ccccccccc} 
& PRIV & SYR & LNY & POP & GSUR & TEXP & CAPEXP & CUREXP & PRIVPUB \\
\hline PRIV & 1.00 & 0.26 & 0.28 & -0.33 & 0.06 & 0.10 & -0.11 & 0.14 & 0.34 \\
SYR & & 1.00 & 0.69 & -0.49 & 0.06 & 0.18 & -0.38 & 0.30 & -0.26 \\
LNY & & & 1.00 & -0.60 & 0.16 & 0.28 & -0.40 & 0.41 & -0.34 \\
POP & & & & 1.00 & -0.16 & -0.44 & 0.14 & -0.51 & 0.03 \\
GSUR & & & & & 1.00 & -0.34 & -0.28 & -0.28 & -0.26 \\
TEXP & & & & & & 1.00 & 0.35 & 0.97 & 0.34 \\
CAPEXP & & & & & & & 1.00 & 0.10 & 0.86 \\
CUREXP & & & & & & & & 1.00 & 0.13 \\
PRIVPUB & & & & & & & & & 1.00
\end{tabular}


Table 3. WLS regression results for expenditure variables, 1970-92. Dependent variable: GYP.

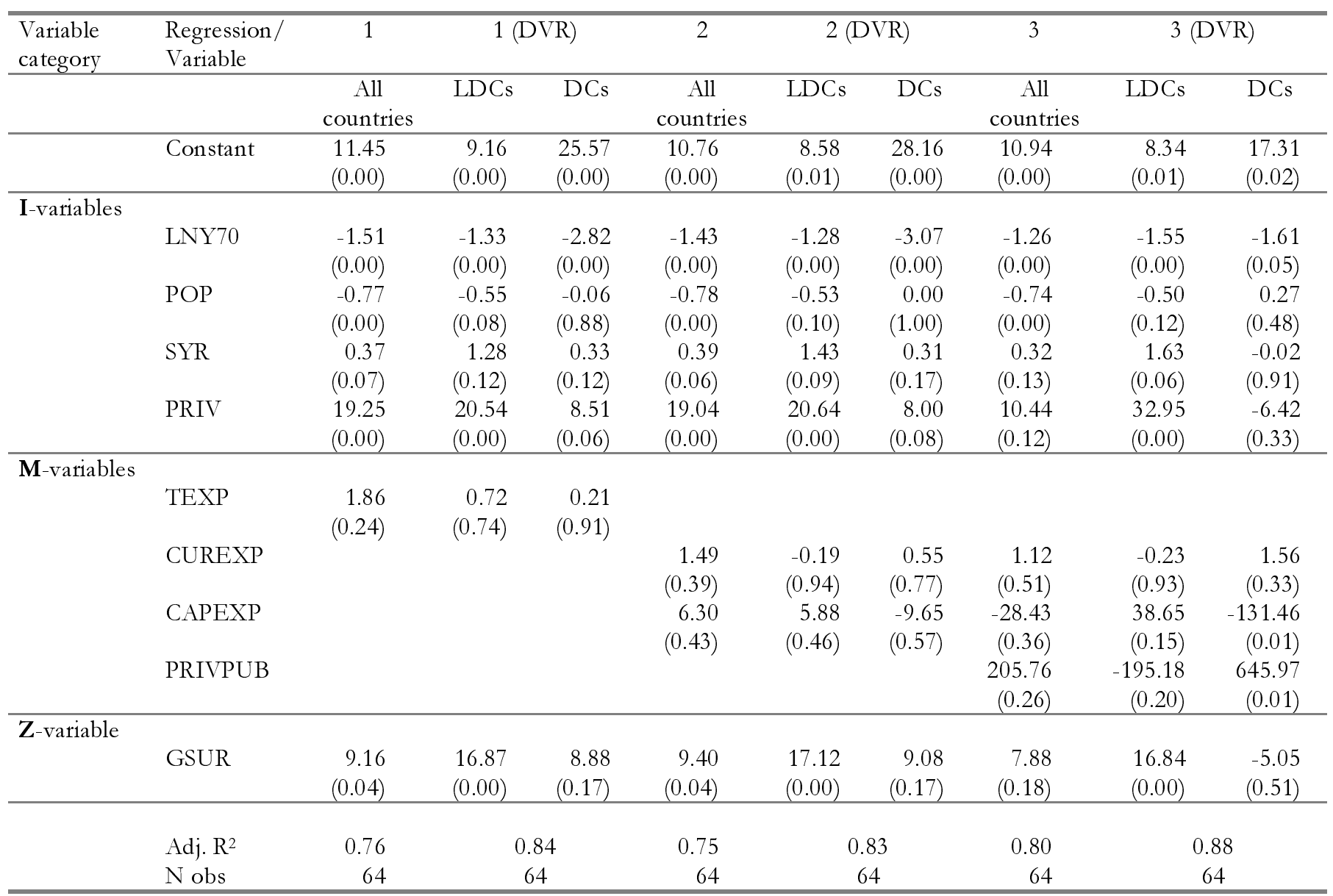

Figures in parenthesis are t-statistic probabilities (i.e. the level of significance).

Table 4. Correlation coefficients for financing variables.

\begin{tabular}{|c|c|c|c|c|c|c|c|c|c|c|c|}
\hline & INV & LNY & SYR & POP & GSUR & TREV & CAPREV & CURREV & TAX & NTAX & SEIG \\
\hline INV & 1.00 & 0.03 & 0.03 & -0.22 & -0.10 & 0.29 & 0.30 & 0.28 & 0.22 & 0.24 & -0.13 \\
\hline LNY & & 1.00 & 0.69 & -0.60 & 0.16 & 0.39 & -0.06 & 0.39 & 0.48 & -0.08 & -0.05 \\
\hline SYR & & & 1.00 & -0.49 & 0.06 & 0.24 & -0.01 & 0.24 & 0.31 & -0.06 & -0.08 \\
\hline POP & & & & 1.00 & -0.16 & -0.56 & -0.01 & -0.56 & -0.59 & -0.10 & 0.23 \\
\hline GSUR & & & & & 1.00 & -0.05 & 0.15 & -0.06 & -0.12 & 0.12 & -0.14 \\
\hline TREV & & & & & & 1.00 & 0.07 & 1.00 & 0.93 & 0.47 & -0.17 \\
\hline CAPREV & & & & & & & 1.00 & 0.04 & -0.06 & 0.26 & 0.08 \\
\hline CURREV & & & & & & & & 1.00 & 0.93 & 0.46 & -0.17 \\
\hline TAX & & & & & & & & & 1.00 & 0.11 & -0.16 \\
\hline NTAX & & & & & & & & & & 1.00 & -0.07 \\
\hline SEIG & & & & & & & & & & & 1.00 \\
\hline
\end{tabular}


Table 5. WLS regression results for financing variables, 1970-92. Dependent variable: GYP.

\begin{tabular}{|c|c|c|c|c|c|c|c|c|c|c|}
\hline \multirow{2}{*}{$\begin{array}{l}\text { Variable } \\
\text { category }\end{array}$} & \multirow{2}{*}{$\begin{array}{l}\text { Regression/ } \\
\text { Variable }\end{array}$} & \multirow{2}{*}{$\begin{array}{c}4 \\
\text { All } \\
\text { countries }\end{array}$} & \multicolumn{2}{|c|}{4 (DVR) } & \multirow{2}{*}{$\begin{array}{c}5 \\
\text { All } \\
\text { countries }\end{array}$} & \multicolumn{2}{|c|}{5 (DVR) } & \multirow{2}{*}{$\begin{array}{c}6 \\
\text { All } \\
\text { countries }\end{array}$} & \multicolumn{2}{|c|}{6 (DVR) } \\
\hline & & & LDCs & DCs & & LDCs & DCs & & LDCs & DCs \\
\hline & Constant & $\begin{array}{r}9.02 \\
(0.00)\end{array}$ & $\begin{array}{r}7.93 \\
(0.02) \\
\end{array}$ & $\begin{array}{l}12.16 \\
(0.17) \\
\end{array}$ & $\begin{array}{r}8.99 \\
(0.00) \\
\end{array}$ & $\begin{array}{r}7.75 \\
(0.03) \\
\end{array}$ & $\begin{array}{l}11.75 \\
(0.24) \\
\end{array}$ & $\begin{array}{r}8.30 \\
(0.00) \\
\end{array}$ & $\begin{array}{r}6.28 \\
(0.04) \\
\end{array}$ & $\begin{array}{l}10.39 \\
(0.35) \\
\end{array}$ \\
\hline I-variables & $\begin{array}{l}\text { INV } \\
\text { LNY70 }\end{array}$ & $\begin{array}{r}12.17 \\
(0.00) \\
-1.04 \\
(0.00) \\
-0.93 \\
(0.00) \\
0.31 \\
(0.08)\end{array}$ & $\begin{array}{r}17.02 \\
(0.00) \\
-1.17 \\
(0.01) \\
-0.53 \\
(0.12) \\
1.78 \\
(0.03)\end{array}$ & $\begin{array}{r}8.72 \\
(0.04) \\
-1.36 \\
(0.13) \\
-0.14 \\
(0.72) \\
0.12 \\
(0.59)\end{array}$ & $\begin{array}{r}12.19 \\
(0.00) \\
-1.04 \\
(0.00) \\
-0.93 \\
(0.00) \\
0.32 \\
(0.10)\end{array}$ & $\begin{array}{r}16.83 \\
(0.00) \\
-1.14 \\
(0.01) \\
-0.53 \\
(0.13) \\
1.78 \\
(0.04)\end{array}$ & $\begin{array}{r}8.68 \\
(0.05) \\
-1.31 \\
(0.22) \\
-0.15 \\
(0.71) \\
0.11 \\
(0.71)\end{array}$ & $\begin{array}{r}11.50 \\
(0.00) \\
-0.93 \\
(0.01) \\
-0.80 \\
(0.00) \\
0.25 \\
(0.17)\end{array}$ & $\begin{array}{r}16.16 \\
(0.00) \\
-0.90 \\
(0.03) \\
-0.45 \\
(0.15) \\
1.94 \\
(0.01)\end{array}$ & $\begin{array}{r}9.11 \\
(0.05) \\
-1.19 \\
(0.31) \\
-0.22 \\
(0.64) \\
0.14 \\
(0.65)\end{array}$ \\
\hline M-variables & $\begin{array}{l}\text { CAPREV } \\
\text { CURREV } \\
\text { TAX } \\
\text { NTAX } \\
\text { SEIG }\end{array}$ & $\begin{array}{l}89.93 \\
(0.00) \\
-0.51 \\
(0.70)\end{array}$ & $\begin{array}{l}82.65 \\
(0.45) \\
-1.95 \\
(0.50)\end{array}$ & $\begin{array}{c}89.77 \\
(0.06) \\
-0.38 \\
(0.80)\end{array}$ & $\begin{array}{r}-0.57 \\
(0.72) \\
-0.34 \\
(0.93)\end{array}$ & $\begin{array}{r}-2.86 \\
(0.41) \\
1.38 \\
(0.81)\end{array}$ & $\begin{array}{r}-0.66 \\
(0.80) \\
0.99 \\
(0.94)\end{array}$ & $\begin{array}{r}-0.89 \\
(0.59) \\
0.01 \\
(1.00) \\
-0.00 \\
(0.00)\end{array}$ & $\begin{array}{r}-4.04 \\
(0.19) \\
-0.30 \\
(0.95) \\
-0.00 \\
(0.00)\end{array}$ & $\begin{array}{r}-0.46 \\
(0.87) \\
-0.99 \\
(0.95) \\
0.01 \\
(0.73)\end{array}$ \\
\hline $\mathrm{Z}$-variable & GSUR & $\begin{array}{r}3.58 \\
(0.59) \\
\end{array}$ & $\begin{array}{l}18.51 \\
(0.00) \\
\end{array}$ & $\begin{array}{l}-5.65 \\
(0.58)\end{array}$ & $\begin{array}{r}3.87 \\
(0.50) \\
\end{array}$ & $\begin{array}{l}17.78 \\
(0.00) \\
\end{array}$ & $\begin{array}{l}-6.32 \\
(0.60)\end{array}$ & $\begin{array}{r}4.01 \\
(0.61) \\
\end{array}$ & $\begin{array}{l}15.93 \\
(0.00) \\
\end{array}$ & $\begin{array}{l}-7.61 \\
(0.56) \\
\end{array}$ \\
\hline & $\begin{array}{l}\text { Adj. } R^{2} \\
\text { N obs }\end{array}$ & $\begin{array}{c}0.80 \\
64\end{array}$ & & & $\begin{array}{c}0.79 \\
64\end{array}$ & & & $\begin{array}{c}0.77 \\
64\end{array}$ & & \\
\hline
\end{tabular}

Figures in parenthesis are t-statistic probabilities (i.e. the level of significance). 
Table 6. Correlation coefficients for developing countries.

\begin{tabular}{c|cccccc} 
& GSUR & GRANT & AID & DEBT & TA & TREV \\
\hline GSUR & 1.00 & -0.48 & -0.42 & -0.62 & -0.34 & 0.00 \\
GRANT & & 1.00 & 0.98 & 0.61 & 0.85 & 0.08 \\
AID & & & 1.00 & 0.52 & 0.92 & 0.01 \\
DEBT & & & & 1.00 & 0.29 & 0.12 \\
TA & & & & & 1.00 & -0.09 \\
TREV & & & & & & 1.00
\end{tabular}

Table 7. OLS regression for LDCs. Dependent variable: GYP.

\begin{tabular}{|c|c|c|c|c|c|}
\hline Variable category & $\begin{array}{l}\text { Regression/ } \\
\text { Variable }\end{array}$ & 8 & 9 & 10 & 11 \\
\hline & Constant & 12.73 & 11.99 & 7.60 & 8.56 \\
\hline & & $(0.00)$ & $(0.00)$ & $(0.02)$ & $(0.02)$ \\
\hline \multicolumn{6}{|l|}{ I-variables } \\
\hline & LNY70 & -1.66 & -1.55 & -0.95 & -1.20 \\
\hline & & $(0.00)$ & $(0.00)$ & $(0.02)$ & $(0.01)$ \\
\hline & POP & 0.48 & -0.56 & -0.52 & -0.44 \\
\hline & & $(0.18)$ & $(0.13)$ & $(0.06)$ & $(0.17)$ \\
\hline & SYR & 0.56 & 0.56 & 0.77 & 1.15 \\
\hline & & $(0.52)$ & $(0.53)$ & $(0.31)$ & $(0.23)$ \\
\hline & INV & 15.11 & 14.50 & 13.-00 & 14.46 \\
\hline & & $(0.00)$ & $(0.00)$ & $(0.00)$ & $(0.00)$ \\
\hline \multicolumn{6}{|l|}{ M-variables } \\
\hline & TREV & -0.79 & -0.51 & & \\
\hline & & $(0.79)$ & $(0.87)$ & & \\
\hline & AID & -27.09 & & & \\
\hline & & $(0.01)$ & & & \\
\hline & GRANT & & -41.56 & & \\
\hline & & & $(0.07)$ & & \\
\hline & TA & & 9.75 & & \\
\hline & & & $(0.82)$ & & \\
\hline & DEBT & & & -1.56 & \\
\hline & & & & $(0.00)$ & \\
\hline & DSR & & & & -0.00 \\
\hline & & & & & $(0.85)$ \\
\hline \multicolumn{6}{|l|}{$\mathbf{Z}$-variable } \\
\hline & GSUR & 13.39 & 11.99 & 6.53 & 18.79 \\
\hline & & $(0.01)$ & $(0.03)$ & $(0.23)$ & $(0.00)$ \\
\hline & Adj. $R^{2}$ & 0.55 & 0.54 & 0.61 & 0.45 \\
\hline & N obs & 38 & 38 & 38 & 38 \\
\hline
\end{tabular}

Figures in parenthesis are t-statistic probabilities (i.e. the level of significance). 